\title{
O KRZEMIENIARSTWIE NEOLITYCZNYM I NEOLITYZACJI ZIEM POLSKICH - WOKÓŁ TEORII, METOD I JĘZYKA
}

\section{ON NEOLITHIC FLINT-KNAPPING AND NEOLITISATION OF POLISH LANDS - ABOUT THE THEORY, METHODS AND LANGUAGE}

\author{
Jolanta Matecka-Kukawka \\ Instytut Archeologii, Pracownia Traseologii \\ Uniwersytet Mikołaja Kopernika \\ ul. Szosa Bydgoska 44/48, 87-100 Toruń \\ Jolanta.Malecka-Kukawka@umk.pl
}

\begin{abstract}
The article is a reflection on the research on the neolithic flint working ongoing in Polish archaeology for over 40 years. Accepting year 1971 as a turning point for the development of a new specialisation, an attempt has been made in the article to assess the impact of the assumptions of the New Archaeology, but also other paradigms, on the study of neolithic flint artefacts. The evaluation was based on the conclusions resulting from, among others, a textual analysis, for the purpose of this article understood as a kind of source of knowledge about more or less consciously accepted theoretical assumptions in studies on flint working, published by various authors, in methods of classifying data in particular, and their position in the process of describing/explaining/interpreting past reality.
\end{abstract}

KEY WORDS: flint working, neolithic, classification in archaeology, archaeological methodology.

\section{WSTĘP}

Tytuł mojego artykułu świadomie nawiązuje do dwu prac autorstwa Jacka Lecha, opublikowanych na łamach Archeologii Polski w latach 1988 i 1989: „O rewolucji neolitycznej i krzemieniarstwie. Część I: Wokół metody” i „O rewolucji neolitycznej i krzemieniarstwie. Część II: Wokół neolityzacji dorzeczy Wisły i Odry”. Od wydania tych artykułów minęło niedawno 25 lat - wystarczająco dużo, by podjąć próbę refleksji nad stanem współczesnej wiedzy o krzemieniarstwie neolitycznym z kilku perspektyw. Jedną z nich jest niewątpliwie wiedza źródłowa, znacząco bogatsza niż ćwierć wieku temu (przynajmniej ilościowo - wystarczy prześledzić pu- 
blikacje dotyczące inwentarzy krzemiennych z kontekstów neolitycznych, wydawane bądź jako oddzielne opracowania, bądź jako integralna część obszerniejszych publikacji, m.in. związanych z uspołecznianiem wyników badań na tzw. wielkich inwestycjach). Jednak nie ta perspektywa była inspiracją do napisania tego tekstu ani też nie będzie ona przedmiotem moich rozważań. Dużo bardziej interesująca wydała mi się problematyka kontekstów teoretycznych, metodologicznych i językowych publikacji poświęconych krzemieniarstwu neolitycznemu i roli, jaką odgrywa wiedza uzyskana dzięki analizom wytworów krzemiennych, stanowiących stały składnik pozostałości po neolitycznym osadnictwie.

Wspomniane dwa obszerne artykuły J. Lecha, mimo że w dużej mierze napisane jako polemiczne z poglądami Bogdana Balcera ${ }^{1}$, w istocie dotyczą dużo szerszego spektrum zagadnień, które można ująć jako próbę refleksji nad uwarunkowaniami teoretycznymi, metodologicznymi i metodycznymi studiów nad krzemieniarstwem społeczności wczesnorolniczych dorzeczy Wisły i Odry wśród polskich badaczy końca lat 80 . XX w. Siłą rzeczy wypowiedź J. Lecha odnosiła się do rzeczywistości archeologicznej, w której (w dużym uproszczeniu) starły się dwie wizje uprawiania $\operatorname{archeologii}^{2}$ - i choć obie współcześnie umieszczane są w tym samym obiektywistycznym modelu poznania ${ }^{3}$, to jednak, jak pisze M. Johnson: „Nowa Archeologia ma dzisiaj ponad 40 lat, ale pytania, które zadała, są najważniejsze dla rozumienia współczesnej teorii i praktyki archeologicznej”' (Johnson 2013, s. 31).

\section{ROZWÓJ REFLEKSJI TEORETYCZNEJ W ARCHEOLOGII I KRZEMIENIARSTWO NEOLITYCZNE - KILKA UWAG Z PERSPEKTYWY POLSKIEJ PRAKTYKI BADAWCZEJ}

Za znaczącą cezurę w rozwoju studiów nad krzemieniarstwem neolitycznym przyjmuje się rok 1971, w którym odbyło się międzynarodowe sympozjum. Stało się ono „Wyrazem ukonstytuowania się krzemieniarstwa neolitycznego jako kierunku badań dysponującego odrębną kategorią źródeł archeologicznych, specyficznymi

\footnotetext{
${ }^{1}$ W środowisku „krzemieniarzy”, również przez samego Bogdana Balcera określane jako „,antybalcer". W anegdotycznej wersji Bogdan Balcer stwierdził (czego byłam świadkiem), że po tej krytyce porzuca studia nad krzemieniarstwem i odda się zagadnieniom budownictwa neolitycznego, co zresztą uczynił, publikując swoją monografię w 2012 r. Jednak w 2002 r., wbrew deklaracjom, opublikował pracę poświęconą krzemieniarstwu: Ćmielów - Krzemionki - Świeciechów. Zwiazki osady neolitycznej z kopalniami krzemienia.

${ }^{2}$ Dzisiaj powszechnie określane jako dwa paradygmaty: kulturowo-historyczny i procesualny, utożsamiany także z Nową Archeologią.

${ }^{3}$ Według propozycji A. Zybertowicza (1995): podziału na obiektywistyczny (OMP) i konstruktywistyczny model poznania (KMP). Podział ten stał się użytecznym narzędziem analitycznym dla refleksji z zakresu historii myśli archeologicznej (por. ostatnio: Rączkowski 2009 [2011], s. 25-26).
} 
metodami, w większości zaczerpniętymi z dorobku archeologii paleolitu oraz charakterystycznymi celami poznawczymi, wzbogacającymi wiedzę o młodszej epoce kamienia [...]” (Lech, 2000, s. 178) ${ }^{4}$. W tym samym tekście autor stwierdza, że „Badania różnych aspektów wytwórczości krzemieniarskiej wspólnot rolniczych stały się od tego czasu odrębną specjalizacją w zakresie badań archeologicznych i jedną $\mathrm{z}$ charakterystycznych cech archeologii polskiej i to w skali przekraczającej granice Europy Środkowej” (Lech 2000, s. 178).

Te istotne z perspektywy historii myśli archeologicznej (wykraczające poza wyznaczane ówczesnymi realiami politycznymi granice) stwierdzenia ${ }^{5}$ odnoszą się do określonego kontekstu historycznego w praktyce badań archeologicznych. W zasadzie biorąc pod uwagę chronologię pojawiania się wypowiedzi, które dzisiaj powszechnie identyfikujemy z nurtem (czy też inaczej: systemem myślowym) Nowej Archeologii ${ }^{6}$, nietrudno zauważyć, że studia nad krzemieniarstwem neolitycznym, ujmowanym przez J. Lecha jako odrębna specjalizacja, ze znaczącymi (pionierskimi?) osiągnięciami polskiej archeologii, mają mniej więcej tyle samo lat. Samo stwierdzenie zbieżności chronologicznej koncepcji Nowej Archeologii (procesualizmu) i badań nad zagadnieniami krzemieniarstwa wspólnot wczesnorolniczych pozbawione kontekstu historyczno-społecznego - może być (słusznie) uznane za manipulację, nic niewnoszącą do historii myśli archeologicznej.

Podejmując ten temat - z pełną świadomością uproszczeń - chciałabym wykazać, że wskazana zbieżność czasowa (mniej więcej czterdziestoletnia) pojawienia się refleksji związanej z krytyką tzw. archeologii tradycyjnej (kulturowo-historycznej) w archeologii (nie mówię tu o polskiej archeologii) i znaczącym rozwojem studiów nad krzemieniarstwem neolitycznym (mówię tu o polskiej archeologii) są w istotny sposób ze sobą powiązane ${ }^{7}$. Chcę przez to powiedzieć, że współczesne oblicze stu-

\footnotetext{
${ }^{4}$ Pokłosiem sympozjum była publikacja: Z badań nad krzemieniarstwem neolitycznym i eneolitycznym (Referaty i komunikaty przedstawione na sympozjum w Nowej Hucie dn. 10, 11 maja 1971 r.), pod redakcją J.K. Kozłowskiego.

${ }^{5}$ Do tej pory nikt nie podważył zasadności wyróżnienia takiej cezury w odniesieniu do badań krzemieniarstwa neolitycznego.

${ }^{6}$ Pozwolę sobie na pominięcie cytowania literatury związanej z tym nurtem w dziejach archeologii. W historii myśli archeologicznej rozdział Nowej Archeologii jest faktem (ostatnio: Johnson 2013, s. 36-50).

${ }^{7}$ Celowo pomijam niezwykle złożoną problematykę marksizmu w polskiej archeologii, który, mówiąc słowami S. Tabaczyńskiego: ,[...] jest i będzie zapewne jeszcze długo przedmiotem skrajnie niekiedy rozbieżnych ocen" (2000, s. 513). Badania nad neolitycznym krzemieniarstwem, z racji przyjmowanej cezury 1971 r. jako początku wyodrębnienia się tej specjalizacji, mieszczą się w końcówce trzeciego (1956-1975) z czterech wyróżnionych przez J. Lecha okresach oddziaływania marksizmu na polską archeologię (1997, s. 210-211). Okres ten miał się charakteryzować stopniowym, powolnym zanikiem marksizmu jako ideologii i dekompozycją marksizmu schematycznego, przyjmowaniem koncepcji i metod z innych teorii oraz szkół naukowych, w tym m.in. (zwłaszcza, jak sądzę, w zakresie badań krzemieniarskich) nowej archeologii amerykańskiej i brytyjskiej archeologii procesualnej (Lech 1997, s. 210).
} 
diów nad inwentarzami krzemiennymi wspólnot wczesnorolniczych w polskiej archeologii (metodyczne i metodologiczne) jest w jakimś sensie konsekwencją postaw badawczych ukształtowanych w czasach krytyki naiwnego naturalizmu archeologii tradycyjnej przez przedstawicieli nurtów modernistycznych procesualizmu i Nowej Archeologii. Te opozycyjne postawy w badaniach nad krzemieniarstwem neolitycznym bardzo dobrze ilustrują wymienione we wstępie artykuły J. Lecha, które można by dzisiaj potraktować jako kolejną, ważną z perspektywy praktyki badawczej archeologów „krzemieniarzy” cezurę w historii myśli pokazującej sposoby konstruowania wiedzy o wytworach krzemiennych w życiu społeczności neolitycznych. Istotę tego etapu definiowałyby słowa wspomnianego autora: „W świetle przedstawionych uwag staje się zrozumiałe, iż brak skłonności badaczy krzemieniarstwa neolitycznego do wprowadzania taksonomii przemysłowej inwentarzy jest przejawem ogólnych tendencji, jakie zarysowują się od wielu lat" (Lech 1988, s. 288).

Rzeczywiście, przyglądając się publikacjom (zwłaszcza młodszych pokoleń badaczy) dotyczącym krzemieniarstwa wczesnych rolników na ziemiach polskich, można stwierdzić, że poza samym autorem koncepcji „,przemysłowej mapy ziem polskich w neolicie" jako źródłowo odmiennego programu konstruowania map kultur wyróżnionych głównie na podstawie cech ceramiki, B. Balcerem ${ }^{8}$, w latach 90. XX w. i później nikt nie podjął się kontynuowania tego zamierzenia. Czy jednak oznacza to rzeczywiste odrzucenie założeń archeologii kulturowo-historycznej w studiach krzemieniarskich i czy w tym konkretnym przypadku (pomijam tu inne zakresy podejmowanych studiów nad przeszłością w polskiej archeologii) mielibyśmy do czynienia z przełomem paradygmatycznym? Odpowiedź na to pytanie nie jest prosta, chociaż postawa metodologiczna części badaczy epoki kamienia mogłaby na to wskazywać. Zauważa to także D. Minta-Tworzowska, stwierdzając, że:

Gdyby udało się udzielić odpowiedzi na pytanie, czy w polskiej archeologii prowadzone są w szerszej skali badania naukowe, które można by uznać za w pełni teoretyczne, byłaby to równocześnie odpowiedź na pytanie, czy nastąpił w niej przełom teoretyczny. Bardziej łączyłabym go z pracami realizującymi postulaty archeologii procesualnej (np. w odniesieniu do epoki kamienia) czy pracami łączącymi procesualizm z innymi teoriami modernistycznymi [...] (Minta-Tworzowska 2000, s. 533).

\footnotetext{
${ }^{8} \mathrm{~W}$ pracach B. Balcera, zwłaszcza tej z 1983 r., czytelne są nawiązania do marksizmu z powołaniem się na leninowską definicję (za W.M. Massonem) przemysłu domowego. Jednak poza deklaracjami dotyczącymi perspektyw badawczych, związanych z gospodarczym znaczeniem krzemienia, w dalszych częściach pracy mamy do czynienia z klasycznym programem szkoły kulturowo-historycznej. W odniesieniu do badań krzemieniarstwa (ale nie tylko) wypada zgodzić się z tezą D. Minty-Tworzowskiej, że ,[...] w zakresie teorii marksizm w polskiej archeologii nie stanowił przełomu - również w sensie metodologicznym. Był on obcy tradycji poznawczej polskiej archeologii, a jedynie uzupełniał model kulturowo-historyczny o nowe pojęcia, zwłaszcza kategorie gospodarcze, co dało archeologii nowy oddech i poszerzało znacznie obszar jej zainteresowań, jednak nie oznaczało zmiany teorii” (2000, s. 532-533).
} 
Ta wypowiedź stanowi klamrę łączącą postawioną wcześniej tezę, że czterdzieści lat studiów nad krzemieniarstwem neolitycznym i czterdzieści lat istnienia paradygmatu Nowej Archeologii to nie jest tylko przypadkowa zbieżność dat.

Powrócę do prekursorów nowych wobec archeologii tradycyjnej koncepcji studiów nad krzemieniarstwem epoki kamienia, którzy w sposób bezpośredni deklarowali swoje postawy teoretyczne, zwłaszcza odnoszące się do fundamentalnego dla rozwiązań metodologicznych rozumienia terminu kultura (jako ekstrasomatycznego czy inaczej: pozabiologicznego sposobu adaptacji człowieka do środowiska naturalnego). Są to Romuald Schild i Jacek Lech, których wymieniam przede wszystkim dlatego, że zaproponowali dwa nieco odmienne systemy klasyfikacji materiałów krzemiennych ${ }^{9}$. J. Lech tworzył swoją klasyfikację (znaną jako „metoda podziału na cztery grupy inwentarzowe") materiałów pracownianych z neolitycznej kopalni krzemienia w Sąspowie (Lech 1970; Dzieduszycka-Machnikowa, Lech 1976), R. Schild zaś niemal 10 lat wcześniej, korzystając z zamysłu S. Krukowskiego, podczas III Sympozjum Paleolitycznego, które odbyło się w Krakowie w 1967 r., przedstawił propozycję klasyfikacji materiałów z pracowni przetwórczych związanych z cyklem mazowszańskim. Była to pierwsza próba stworzenia systemu klasyfikacji materiałów schyłkowopaleolitycznych, dostosowana do analizy przemysłów z eksploatacją rdzeni dwupiętowych ${ }^{10}$. Bardziej rozbudowaną wersję ,,klasyfikacji dynamicznej" wraz z krytyką tradycyjnych metod postępowania badawczego (które uznano za „wysoce nieproduktywne i dostarczające tylko ograniczonych, często nawet fałszywych wiadomości o tych odległych w czasie społeczeństwach kuli ziemskiej” [Schild, Marczak, Królik 1975, s. 7]) opublikowano w 1975 r. Wymienionych autorów klasyfikacji (także innych, wpisujących się w ten paradygmat - lecz na omawianie ich prac nie ma tutaj miejsca) łączyło przekonanie, że archeologia powinna badać przede wszystkim zjawiska kulturowe, które wyłaniają się w wyniku drobiazgowej analizy materiałów, podziały taksonomiczne należy zaś traktować jako punkt wyjścia do dalszych badań. Zaproponowana przez R. Schilda dynamiczna klasyfikacja materiałów krzemiennych (wraz z immanentną metodologią postę-

\footnotetext{
${ }^{9} \mathrm{~W}$ następnych latach były one przyjmowane przez innych badaczy krzemieniarstwa - i mimo że obaj twórcy tych systemów klasyfikacyjnych wychodzili z podobnych inspiracji metodologicznych (zwłaszcza L. i S. Binfordów), to w dość intrygujący sposób te dwie propozycje klasyfikacyjne zaczęły być traktowane jako opozycyjne. Niekiedy, w mniej formalnych sytuacjach, dyskusje nad zasadnością stosowania którejś z metod klasyfikacji, zwłaszcza w odniesieniu do neolitycznych materiałów z osad, przypominały wykłady z „mniemanologii stosowanej”: „O wyższości Świąt Wielkiej Nocy nad Świętami Bożego Narodzenia” Jana Tadeusza Stanisławskiego, wybitnego satyryka, aktora i autora tekstów piosenek.

${ }^{10}$ Pełna propozycja tego systemu klasyfikacyjnego została opublikowana w Unconventional Archaelogy. New Approaches and Goals in Polisch archaeology w 1980 r., zatytułowana „Introduction to Dynamic Technological Analysis of Chipped Stone Assemblages” (por. Burdukiewicz 2000, s. 31-33; Schild 2000, s. 41-43).
} 
powania badawczego) dość powszechnie została przejęta przez badaczy paleolitu i mezolitu ${ }^{11}$.

Metoda ta została przyjęta przez badaczy, którzy w trakcie swojej działalności podjęli się opracowania neolitycznych matriałów krzemiennych. Czy jednak mamy do czynienia z konsekwentnym przyjęciem zaplecza teoretycznego? Postaram się na to pytanie odpowiedzieć, przywołując kilka ważniejszych publikacji (monografii) poświęconych neolitycznemu krzemieniarstwu, które ukazały się w ostatnich latach.

\section{O PRAKTYCE BADAŃ KRZEMIENIARSTWA NEOLITYCZNEGO - METODA KLASYFIKACJI JAKO MANIFEST POSTAWY TEORETYCZNEJ?}

Postawione wyżej pytanie jest nawiązaniem do poruszonej niedawno problematyki na łamach Archeologii Polski w artykule „Retoryczne środki językowe jako wskaźniki postaw poznawczych badaczy przeszłości” (Cyngot, Zalewska 2012, s. 57-78). Zasadnicza wypowiedź w tym tekście odnosi się wprawdzie do współcześnie istniejących dwu postaw - wspólnot interpretacyjnych badaczy - „obiektywistów” i „konstruktywistów”. Sądzę jednak, że zaproponowany sposób odczytywania tekstów naukowych może być użyteczny z perspektywy poruszanych w tym artykule problemów.

W dyskursie naukowym nie należy rozpatrywać oddzielnie poziomu formy i znaczenia wypowiedzi, są bowiem nierozdzielne ze względu na zasadniczą rolę wartościowania i logicznego porządkowania, a obserwacje i wnioski dotyczące obu tych aspektów nieustannie się przeplatają. Stwarza to podstawę do analizowania warstwy słownej tekstów jako językowego wskaźnika grup o wspólnej tożsamości - reprezentantów wspólnot interpretacyjnych kierujących się w swych pracach tym samym paradygmatem (Cyngot, Zalewska 2012, s. 70).

Jak wspomniałam wcześniej, wskazując na wspólne zaplecze metodologiczne twórców systemów klasyfikacyjnych, badacze krzemieniarstwa neolitycznego dla potrzeb realizowanych badań w większości przejmowali jeden $\mathrm{z}$ dwu dobrze zdefiniowanych systemów klasyfikacyjnych, dokonując w nich (wraz z dopływem nowych materiałów wcześniej nieznanych lub też podejmując się opracowania zagadnień krzemieniarstwa neolitycznego z uwzględnieniem materiałów archiwalnych) pewnych modyfikacji wynikających ze specyfiki materiałów (np. Lech 1986, s. 74-90; 1981, s. 10-12; Kabaciński 2010, s. 9-10; Małecka-Kukawka 1987, s. 121-139; Zakościelna 1996, s. 9-11). Jest to praktyka zrozumiała, ponieważ systemy klasyfikacji źródeł były tworzone w celu analizy określonych struktur archeologicznych, co

\footnotetext{
${ }^{11}$ Szczegółowe omawianie postaw teoretycznych badaczy starszej i środkowej epoki kamienia nie jest przedmiotem tego szkicu.
} 
jasno sformułowano w pracy z 1975 r.: „Lista ta nie ma charakteru uniwersalnego i jej zastosowanie ogranicza się wyłącznie do omawianych tu inwentarzy późnomezolitycznych. Konstrukcja tego rodzaju list jest całkowicie zależna od charakteru technologicznego materiału i celów, którym ma służyć" (Schild, Marczak, Królik 1975, s. 13).

„Klasyfikacja dynamiczna” R. Schilda została zaadaptowana przez niektórych badaczy dla potrzeb studiów nad krzemieniarstwem neolitycznym ${ }^{12}$. W swych publikacjach Autorzy zgodnie piszą: „Całość materiałów opracowałam tak samo jak w przypadku grobowca 8 , bazując w dużej mierze na pracy R. Schilda, M. Marczak, H. Królik (1975)” (Niesiołowska-Śreniowska 1986, s. 202); „Ich charakterystyki technologicznej dokonano stosując założenia tzw. typologii dynamicznej (Schild, Marczak, Królik 1975), adaptując je (rozszerzając) do specyfiki materiałów neolitycznych (Domańska 1975; Domańska, Kabaciński 2000). Ponieważ zalety takiego sposobu ujęcia materiałów krzemiennych są powszechnie znane i akceptowane, nie ma powodu do ich ponownego przedstawiania w tym miejscu" (Kabaciński 2010, s. 9-10); „Analiza ogólnej struktury badanych inwentarzy przeprowadzona została przy wykorzystaniu zasad dynamicznej klasyfikacji technologicznej, której założenia metodyczne zawarte zostały w pracy Romualda Schilda, Marii Marczak i Haliny Królik (1975)" (Domańska 2013, s. 17).

Deklaracje te w sposób jednoznaczny (przynajmniej w warstwie słownej) informują o tożsamości metodycznej (ale także metodologicznej, co wprawdzie przez cytowanych autorów nie zostało napisane wprost, ale skoro piszą o przyjęciu założeń dynamicznej klasyfikacji technologicznej, to należy zakładać, że przedstawiona w 1975 r. metodologia postępowania badawczego jest przez nich także w pełni akceptowana). Czy rzeczywiście w publikacjach dotyczących krzemieniarstwa neolitycznego znajdziemy, poza samą metodą klasyfikacji, pozostałe składniki postępowania badawczego, przedstawionego w Późnym mezolicie...? Nie można odpowiedzieć na to pytanie bez przeprowadzenia analizy tekstualnej tej pracy.

W metodologii Nowej Archeologii przyjęto założenie o istnieniu dwóch poziomów tworzenia wiedzy archeologicznej. Pierwszy polega na drobiazgowej analizie źródeł archeologicznych w celu stworzenia jak najlepszej bazy informacji o przeszłych systemach kulturowych. Poziom drugi miał polegać na zastosowaniu takiej teorii (zaczerpniętej przede wszystkim z antropologii kulturowej), która w możliwie wyczerpujący sposób połączy te informacje w jedną całość i pozwoli na sformułowanie kulturowych znaczeń, co w rezultacie umożliwi na ich podstawie zrekon-

\footnotetext{
${ }^{12}$ Wymienię tu badaczy, którzy od lat podejmowali tę problematykę i są autorami nie tylko opracowań źródłowych, lecz także prac o charakterze monograficznym - E. Niesiołowska-Śreniowska, L. Domańska, J. Kabaciński. Warto zwrócić uwagę na fakt, że wspomniani badacze część swojej pracy naukowej (niekiedy znaczącą) poświęcili studiom nad wcześniejszymi okresami epoki kamienia, co zapewne pozostaje w związku z przyjmowanym przez nich, dla potrzeb analiz materiałów neolitycznych, systemem klasyfikacyjnym.
} 
struowanie przeszłej rzeczywistości społecznej. Procedura wyjaśniania składa się z explanansu i explanandum (m.in. Marciniak 2012, s. 39-46), co innymi słowy oznacza, że poziom drugi nie może obejść się bez pierwszego, pozostanie zaś tylko na poziomie pierwszym nie daje możliwości stworzenia wiedzy archeologicznej, prezentuje on bowiem tylko klasyfikację źródeł krzemiennych. Prawidłowa wiedza archeologiczna zatem musi łączyć te dwa poziomy w jedną całość.

W Późnym mezolicie... wspomniane dwa poziomy tworzenia tej wiedzy przyjmują postać dwu rozdziałów: I. Metodyka i II. Zastosowanie. Rozdział II ma odpowiadać drugiemu etapowi postępowania, ma on swoją ścisłą logikę, zgodnie z którą każdy kolejny krok odsłania coraz więcej treści zawartych w badanym materiale, tak że staje się on coraz bardziej powiązany z przeszłą rzeczywistością kulturową. Są to głównie treści o charakterze opisowym, z których Autorzy wyciągają wnioski wynikające bezpośrednio z przeprowadzonych analiz, jednak mają one już status wiedzy powstałej w wyniku interpretacji nieistniejącej w czystym opisie. Najpierw (1) zaprezentowane zostaje tło rozważań $\mathrm{w}$ postaci opisu stanowisk, $\mathrm{z}$ których pochodzi materiał, co wpisuje go w kontekst odkrycia, a także przypisuje dany inwentarz do konkretnego stanowiska (w sensie geograficznym). Dalej (2) następuje próba odtworzenia środowiska geograficznego każdego stanowiska, charakterystycznego dla czasów, gdy wydobyty materiał był produkowany i użytkowany, co ma znaczenie, ponieważ warunki środowiskowe mogły w istotnym stopniu wpływać na sposób życia przeszłych społeczności, także i na rodzaj wytwarzanych narzędzi oraz to, jak ich używano. W dalszej kolejności pojawia się główna część interpretacji wstępnej (3-5), w której autorzy pod różnym kątem badają inwentarze, dzięki czemu uzyskują informację o ich cechach charakterystycznych, a zatem również najbardziej podstawową wiedzę o ludziach wytwarzających i używających tych zespołów narzędzi. Dzięki temu udaje się w podrozdziale 3. wydzielić trzy wyraźnie różne systemy gospodarki surowcowej, a także wskazać na co najmniej częściową zależność struktury inwentarzy od rodzaju użytkowanego surowca. Z kolei skomplikowane metody statystyczne wprowadzone $\mathrm{w}$ podrozdziale 4 . prowadzą do następującego wniosku: „Powyższe porównania szeregu kategorii reprezentowanych w omawianych inwentarzach wskazują na znaczną stabilność technologiczną całości materiałów i w ramach poszczególnych ugrupowań" (Schild, Marczak, Królik 1975, s. 94). Pokazuje to, jak zaawansowane muszą być metody badawcze w odniesieniu do materiałów z tak odległej przeszłości, aby móc uzyskać na ich podstawie jakąkolwiek wiedzę. Ostatni podrozdział (5) części wstępnej interpretacji stanowi próbę wykrycia jednostek siedliskowych o charakterze mieszkalnym lub funkcjonalnym ${ }^{13}$. Dopiero po ustaleniu tej najbardziej podstawowej wiedzy na temat badanych inwentarzy autorzy

\footnotetext{
${ }^{13}$ Warto w tym miejscu wskazać na zbieżność między podrozdziałami opisu - 2, 3, 4 - a podrozdziałami interpretacji - 3, 4, 5 (kolejno: analiza morfologiczna grupy narzędziowej - elementy zróżnicowania technologicznego zespołów; analiza funkcji narzędzi krzemiennych - elementy zróżnicowania taksonomicznego zespołów narzędzi; analiza przestrzenna zalegania zabytków - elementy zróżnicowania przestrzennego).
} 
przechodzą do głównej części interpretacji (6), w której starają się przekuć uzyskaną wiedzę przedmiotową na wiedzę podmiotową, dotyczącą działalności ludzi, której pozostałością są odkryte na konkretnych stanowiskach inwentarze. Okazuje się, że cała wiedza przedmiotowa jest jedynie podbudówką pod wiedzę o tym, jak mogli żyć dawni ludzie, a co za tym idzie - wszelkie przeprowadzone wcześniej analizy i badania w całym swym wieloaspektowym zróżnicowaniu i skomplikowaniu mają swój ściśle określony cel, bardzo odległy od samej typologizacji czy wydzielenia jednostek kulturowych, a poza tym wskazują na niewystarczalność tych ostatnich w ich jedynie historycznej perspektywie. Niewątpliwie w porównaniu z paradygmatem kulturowo-historycznym w Późnym mezolicie... próba spojrzenia na człowieka jest wyraźnie antropologiczna, co oznacza, że ważne staje się, jak ci ludzie żyli i co ich kształtowało, w jaki sposób się organizowali, a w ostatecznej perspektywie: jak funkcjonowali na poziomie społecznym (Schild, Marczak, Królik 1975, s. 125). Odpowiedź, jaką uzyskują w tym zakresie autorzy, nie jest szczególnie imponująca ze względu na ograniczenia dostępnego materiału ${ }^{14}$, wskazuje jednak w sposób zasadniczy: „na niezwykłą kompleksowość i współzależność obserwowanych faktów i przypuszczalnych ich przyczyn, niemożliwych do uchwycenia w kręgu tradycyjnego poszukiwania zróżnicowań kulturowych" (Schild, Marczak, Królik 1975, s. 125). Wykazują oni dużą świadomość interpretacyjną, gdyż, po pierwsze, nigdzie nie wykraczają swoimi wnioskami poza to, co wynika bezpośrednio z dostrzeżonych faktów; po drugie, rozumieją własne ograniczenia interpretacyjne i mają świadomość, że ich interpretacja jest tylko pewnym przybliżeniem tego, co mogło istnieć w przeszłości, a nie pełnym i ostatecznym stwierdzeniem. Dlatego mimo że dawna rzeczywistość kulturowa nie jest odtworzona w sposób bardzo szczegółowy, to jednak wskazuje na istnienie konkretnych ludzi, którzy w jej ramach adaptowali się po swojemu do otaczającej ich rzeczywistości, a systemu wytworzonej przez nich kultury nie da się uprościć do obiektywnych kategorii badacza i lepiej aby pozostał otwarty na propozycje interpretacyjne niż był zamknięty w ramach zafałszowującej go totalnej (dziejowej) wizji przeszłości ${ }^{15}$.

\footnotetext{
${ }^{14} \mathrm{~W}$ zasadzie udaje im się ustalić, że analizowany przez nich materiał jest śladem egzystencji pojedynczych lub też czasowo połączonych paru rodzin parających się łowiectwem o charakterze traperskim, uprawianym w ramach luźnych ugrupowań społecznych (s. 126). Ustalono także pewną cykliczność osadnictwa, istnienie niezaawansowanego systemu wymiany oraz podobną postawę technologiczno-instrumentalną, która przy zarysowanych podobieństwach struktury społecznej może wskazywać, że analizowane inwentarze pozostawiły społeczności o bardzo zbliżonym lub identycznym systemie adaptacji (kulturze) związanym ze środowiskiem leśnym środkowego holocenu Polski (s. 126). Jednocześnie podkreślają, że w takim systemie zaobserwowane zróżnicowania układów technologiczno-instrumentalnych są głównie odbiciem okoliczności funkcjonalnych, towarzyszących powstaniu danego zespołu narzędzi, a nie różnic kulturowych (s. 126).

${ }^{15}$ Przedstawiona próba analizy tekstualnej jest przetworzonym fragmentem obszernej pracy magisterskiej Andrzeja Słowikowskiego: „Obraz człowieka w polskiej archeologii XX wieku”, napisanej pod moim kierunkiem i obronionej w $2009 \mathrm{r}$.
} 
Wypada powrócić do próby odpowiedzi na pytanie, czy w badaniach krzemieniarstwa neolitycznego mamy do czynienia z konsekwentnym - jak by mogły wskazywać deklaracje autorów - przestrzeganiem reguł wytwarzania wiedzy w duchu paradygmatu procesualnego? Po części odpowiedzi na to pytanie udzielił J. Lech we wspomnianych artykułach polemicznych. Można stwierdzić, że samo zastosowanie „dynamicznej klasyfikacji technologicznej” w analizie materiałów krzemiennych nie oznacza $\mathrm{w}$ żaden sposób zmiany paradygmatu. J. Lech nazwał takie postępowanie mianem metody „hipotetyczno-indukcyjnej” (Lech 1989, s. 58), którą można sprowadzić do następującego toku postępowania:

[...] punktem wyjścia są wstępne hipotezy dotyczące częściowo mezolitycznej genezy niektórych kultur neolitycznych w dorzeczu Wisły i Odry, sformułowane w literaturze przedmiotu niezależnie od badań krzemieniarskich [w duchu paradygmatu kulturowo-historycznego - przyp. J. M.-K.]. Na podstawie wiedzy pozaźródłowej autorzy prac omawianych w dalszym ciągu artykułu starają się mniej lub bardziej otwarcie od początku analizy rozpatrywanych inwentarzy udowodnić słuszność akceptowanej wcześniej hipotezy bez pełnoprawnego, obiektywnego, uwzględniania innych, odmiennych hipotez. Prezentowany tok rozumowania jest pozornie indukcyjny i kończy się potwierdzeniem przyjmowanej od początku hipotezy (Lech 1989, s. 58).

Czy w pracach poświęconych zagadnieniom krzemieniarstwa neolitycznego opublikowanych w ostatnich latach można zauważyć znaczące zmiany w procedurach badawczych? Odniosę się tu pokrótce do dwu monografii, w których Jacek Kabaciński i Lucyna Domańska deklarują przyjęcie „dynamicznej klasyfikacji” Romualda Schilda jako sposobu analizy źródeł (te same deklaracje są zawarte w wielu artykułach prezentujących neolityczne inwentarze krzemienne). Nie sposób w tym krótkim tekście przeprowadzić tak szczegółowej analizy tekstualnej, jaką przedstawiłam w odniesieniu do pracy Późny mezolit... Jednak już spisy treści dają pewne sugestie o przyjmowanym przez Autorów postępowaniu badawczym. I tak w pracy J. Kabacińskiego Przemiany wytwórczości krzemieniarskiej społeczności kultur wstęgowych na Kujawach strefy wielkodolinnej Niżu Polskiego (Kabaciński 2010) można zauważyć, że jej układ w żaden sposób nie odpowiada procedurze badawczej przedstawionej w monografii z 1975 r. Zasadniczo odpowiednik poziomu I, czyli etapu drobiazgowej analizy źródeł, został umieszczony w końcowej części zatytułowanej „Materiały” (5), pełniącej w jakimś sensie rolę aneksu do tekstu podstawowego, monografię zaś otwiera rozdział „Zarys historii osadnictwa, systematyki i chronologii społeczności kultury ceramiki wstęgowej rytej” (1). A zatem już na początku pracy przedstawiono pewną wizję osadnictwa (aspekt społeczny), systematyki (aspekt kulturowy) i chronologii (aspekt czasowy), które zostały ustalone niezależnie od źródeł krzemiennych. Wynika z tego, że istota wypracowania obiektywnej wiedzy na temat dawnych społeczności dzięki zastosowaniu odpowiednich procedur, w tym klasyfikacji materiałów krzemiennych (jak miało to miejsce w Późnym 
mezolicie...), w pracy J. Kabacińskiego została osiągnięta bez nich. Autor napisał: „Prezentowana praca poświęcona jest prezentacji wytwórczości krzemieniarskiej społeczności wstęgowych, a zasadniczym jej celem jest pokazanie całokształtu przemian, jakie w jej ramach zachodziły w strefie wielkodolinnej Niżu ..." (Kabaciński 2010, s. 7). Ów całokształt przemian sprowadza się do prostego (tradycyjnego) porównania inwentarzy z różnych stanowisk przypisanych do kultury ceramiki wstęgowej rytej i późnej ceramiki wstęgowej, wzbogaconych wykresami (obejmującymi m.in. podstawowe typy narzędzi w KCWR i KPCW, frekwencję drapaczy odłupkowych w KCWR i KPCW, drapaczy wiórowych czy półtylczaków) dotyczącymi wyłącznie przeanalizowanych przez autora inwentarzy. Porównanie z inwentarzami z rejonów sąsiednich (Dolny i Górny Śląsk, Małopolska, ziemia chełmińska i Pomorze, ziemia pyrzycka i rejon dolnej Odry) (Kabaciński 2010, s. 107-130, 169-179) ma charakter opisowy i w dużej mierze prezentuje wnioski ustalone przede wszystkim poza źródłami krzemiennymi. Już samo stwierdzenie zamieszczone na początku wspomnianego rozdziału: „Wyżej wymienione prowincje kulturowe mają w relacji do strefy wielkodolinnej Niżu zupełnie odmienny charakter" (Kabaciński 2010, s. 107) pokazuje, że w istocie analiza źródeł krzemiennych nie była niezbędna dla sformułowania takiej konkluzji.

Bardzo podobny charakter, jeśli chodzi o konstrukcję pracy, ma monografia L. Domańskiej: Krzemieniarstwo horyzontu klasycznowióreckiego kultury pucharów lejkowatych na Kujawach (Domańska 2013). Trudno tu doszukiwać się tak wyraźnych i spójnych z metodologią procesualną poziomów wytwarzania wiedzy obecnych w Późnym mezolicie... Głównymi częściami w pracy L. Domańskiej są rozdziały II-V, zatytułowane „Prezentacja materiałów z obszarów próbnych” (II), „Wczesnowiórecki kontekst genetyczny krzemieniarstwa klasycznowióreckiego na Kujawach” (III), „Krzemieniarstwo kujawskich społeczności klasycznowióreckich” (IV) i „Klasycznowiórecki model krzemienarstwa. Protoplaści, kontynuatorzy i epigoni” (V). Trudno na podstawie spisu treści i tytułów rozdziałów wyznaczyć poziomy tworzenia wiedzy (odpowiednio I i II). Pod względem objętości (s. 17-87) rozdział II stanowi najobszerniejszą część pracy. Autorka rozpoczyna go od słów: „Zasadniczym celem tego rozdziału jest charakterystyka inwentarzy krzemiennych KPL z dwóch wydzielonych obszarów próbnych, tj. środkowego odcinka dorzecza Tążyny i Pagórów Radziejowskich" (Domańska 2013, s. 17). Byłby to więc poziom pierwszy (?), kolejne zaś mogłyby odpowiadać poziomowi II (?), przynajmniej mogłoby to wynikać z ich tytułów. Jednak zawartość rozdziału III jest omówieniem (ilustrowanym kilkoma diagramami blokowymi) danych przedstawionych wcześniej w rozdziale II (i liczy zaledwie 5 stron), a omówione w nim stanowiska mają być wczesnowióreckim kontekstem genetycznym krzemieniarstwa klasycznowióreckiego. Ale ta kwalifikacja kulturowo-chronologiczna nie została ustalona w wyniku przeprowadzonej analizy materiałów krzemiennych, a przede wszystkim ceramiki (Domańska 2013, s. 18, 25, 27). Także rozdział IV trudno uznać za odpowiadający 
poziomowi rozdziału II, gdyż, jak pisze autorka: „Celem niniejszego rozdziału jest podsumowanie charakterystyki obu inwentarzy” (Domańska 2013, s. 95). Tytuł kończącego monografię rozdziału $\mathrm{V}$ (poza jednostronicowym zakończeniem) zapowiada prezentację „Klasycznowóreckiego modelu krzemieniarstwa”, która mogłaby odpowiadać poszukiwanemu przeze mnie poziomowi II. Jednak, jak dowiadujemy się z treści, dotyczy on „protoplastów” - czyli krzemieniarstwa wczesnowióreckiego (inwentarze przypisane tej chronologii za sprawą ustaleń ceramicznych), kontynuatorów - czyli krzemieniarstwa lubońsko-radziejowskiego (ustalenia jak wcześniej), oraz epigonów - krzemieniarstwa ludności kultury amfor kulistych (co w prosty sposób pokazuje, że Autorka nazywając krzemieniarstwo KAK epigonami norm klasycznowióreckich, przyjmuje ustalenia przede wszystkim ceramiczne i jednocześnie akceptuje nie przez wszystkich podzielaną prostą, ewolucyjną (?) zmianę kultury pucharów lejkowatych w kulturę amfor kulistych) ${ }^{16}$. Podsumowując: w monografiach L. Domańskiej i J. Kabacińskiego trudno doszukać się tak charakterystycznych dla paradygmatu procesualnego procedur (poziomów) konstruowania wiedzy o przeszłości. W zasadzie czytelny jest jedynie poziom pierwszy - opisu, czyli klasyfikacji źródeł.

\section{PODSUMOWANIE}

Deklaracje zastosowania systemu klasyfikacji materiałów, zaczerpnięte z modelowej dla nurtu procesualnego pracy R. Schilda, M. Marczak i H. Królik, nie oznaczają przejęcia sposobu wytwarzania wiedzy. Poziom drugi, czyli zastosowanie odpowiedniej teorii antropologicznej w celu połączenia wiedzy wynikającej ze szczegółowych, wieloaspektowych analiz źródeł w spójną wizję dawnej rzeczywistości, w cytowanych syntezach krzemieniarstwa neolitycznego sprowadzają się do przyjęcia istniejących już ustaleń dokonanych na podstawie innych źródeł archeologicznych (przede wszystkim ceramiki). Materiały krzemienne są w pewnym sensie koniecznym (z powodu samego faktu współwystępowania $\mathrm{z}$ innymi materiałami) dodatkiem, który należy „opracować”, wnioski zaś płynące z ich analizy są zależne od ustaleń niekrzemieniarskich. Tę sytuację trafnie opisał J. Lech w odniesieniu do praktyki badawczej lat 70. i 80. Można więc stwierdzić, że w zakresie badań krzemieniarstwa neolitycznego trudno mówić o przełomie paradygmatycznym, przynajmniej w odniesieniu do części twórców wiedzy w tym zakresie. Nastąpiło w jakimś sensie połączenie (które trudno uznać za twórcze) pewnych procedur analitycznych i dość powierzchownej warstwy językowej, zaczerpniętych z nurtu

\footnotetext{
${ }^{16}$ Nie wdając się w szczegółowe rozważania, wskażę tylko na podnoszony wielokrotnie ewentualny udział społeczności kultury późnej ceramiki wstęgowej w genezie kultury amfor kulistych (np. Szmyt 1996, s. 269-275).
} 
procesualnego z praktyką właściwą dla szkoły kulturowo-historycznej. O ile w klasycznym ujęciu procesualnym (krytykowanym przecież od lat) można było doszukiwać się wypowiedzi o twórcach wytworów materialnych (człowieku i jego funkcjonowaniu na poziomie społecznym), o tyle w wielu współczesnych publikacjach dotyczących zagadnień związanych z krzemieniarstwem neolitycznym, dzięki którym wiemy więcej o krzemieniach ${ }^{17}$, ponownie tego człowieka zgubiono - jeśli oczywiście kiedykolwiek był odnaleziony (nie odnosi się to do praktyki badawczej archeologii w ogóle, ponieważ dzieje się w niej bardzo dużo, co dobrze wróży na przyszłość).

Być może konsekwencją takiego niefrasobliwego eklektyzmu (a poważniej słabości metodologicznej) opracowań krzemieniarstwa jest absolutne pominięcie neolitycznych źródeł krzemiennych (i mimo wszystko dość sporej wiedzy na ich temat) w dziele M. Nowaka Drugi etap neolityzacji ziem polskich (Nowak 2009), co może być interesującą inspiracją do napisania odrębnej pracy.

\section{BIBLIOGRAFIA}

Balcer B.

1983 Wytwórczość narzędzi krzemiennych w neolicie ziem Polski. Wrocław-Warszawa-Kraków-Gdańsk-Lódź: Ossolineum.

Balcer B.

2002 Ćmielów-Krzemionki-Świeciechów. Zwiąki osady neolitycznej z kopalniami krzemienia. Warszawa: Wydawnictwo Instytutu Archeologii i Etnologii PAN.

Balcer B.

2012 Budownictwo mieszkalne i gospodarcze w neolicie ziem Polski. Warszawa: Wydawnic-

Burdukiewicz J.M. two Instytutu Archeologii i Etnologii PAN.

2000 Problematyka paleolitu dolnego i środkowego w świetle badań archeologów polskich. W: M. Kobusiewicz, S. Kurnatowski (red.), Archeologia i prahistoria polska w ostatnim Cyngot D., Zalewska A. pótwieczu (s. 27-38). Poznań: Wydawnictwo Poznańskiego Towarzystwa Przyjaciół Nauk.

2012 Retoryczne środki językowe jako wskaźniki postaw poznawczych badaczy przeszłości. Archeologia Polski, 47(1-2), s. 57-78.

Domańska L.

2013 Krzemieniarstwo horyzontu klasycznowióreckiego kultury pucharów lejkowatych na Kujawach. Łódź: Wydawnictwo Uniwersytetu Łódzkiego.

\footnotetext{
${ }^{17}$ Najtrafniej oddają to stwierdzenia: „Materiały krzemienne ze stanowiska Przybranówek 43 kontynuują tradycje krzemieniarstwa »sarnowskiego«” czy „Materiały krzemienne z Poczałkowa 38 stanowią antycypację norm znanych z krzemieniarstwa klasycznowióreckiego, udokumentowanego najpełniej w osadzie w Wilkostowie 23/24. Oba inwentarze łączy podobna strategia w zakresie wykorzystywanych surowców [...]" (Domańska 2013, s. 93). Podobnie brzmiące metafory są właściwe dla archeologii tradycyjnej, która mimo odnotowywanych w historii myśli archeologicznej przełomów paradygmatycznych, jak się okazuje, ma się całkiem dobrze.
} 
Dzieduszycka-Machnikowa A., Lech J.

1976 Neolityczne zespoły pracowniane z kopalni krzemienia w Sąspowie. Polskie Badania Archeologiczne, 19. Wrocław-Warszawa-Kraków-Gdańsk: Ossolineum.

Johnson M.

2013 Teoria archeologii. Wprowadzenie. Kraków: Wydawnictwo Uniwersytetu Jagiellońskiego.

Kabaciński J.

2010 Przemiany wytwórczości krzemieniarskiej społeczności kultur wstęgowych strefy wielkodolinnej Niżu Polskiego. Poznań: Wydawnictwo Instytutu Archeologii i Etnologii PAN.

Kozłowski J.K. (red.)

$1971 \quad Z$ badań nad krzemieniarstwem neolitycznym i eneolitycznym (Referaty $i$ komunikaty przedstawione na sympozjum w Nowej Hucie dn. 10, 11 maja 1971 r.). Kraków.

Kozłowski J.K.

1986 Przemysł krzemienny społeczności jordanowskiej z Tyńca Małego, gm. Kobierzyce. Silesia Antiqua, 28, s. 74-90.

Lech J.

1970 Neolityczna pracownia krzemieniarska w Sąspowie, pow. Olkusz, Warszawa. [Praca magisterska w maszynopisie, przechowywana w Katedrze Archeologii Pradziejowej i Wczesnośredniowiecznej Uniwersytetu Warszawskiego].

Lech J.

1988 O rewolucji neolitycznej i krzemieniarstwie. Część I: Wokół metody. Archeologia Polski, 33(2), s. 273-345.

Lech J.

1989 O rewolucji neolitycznej i krzemieniarstwie. Część II: Wokół neolityzacji dorzeczy Wisły i Odry. Archeologia Polski, 34(1), s. 55-125.

Lech J.

1997 Małowierni. Spór wokół marksizmu w archeologii polskiej lat 1945-1975. Archeologia Polski, 42(1-2), s. 175-232.

Lech J.

2000 Muzeum Archeologiczne w Krakowie i rozwój badań krzemieniarstwa neolitycznego do 1971 r. W: J. Rydzewski (red.), 150 lat Muzeum Archeologicznego w Krakowie (s. 173-184). Kraków: Muzeum Archeologiczne.

Małecka-Kukawka J.

1987 Krzemieniarstwo kultury pucharów lejkowatych na ziemi chełmińskiej. W: T. Wiślański (red.), Neolit i początki epoki brąu na ziemi chetmińskiej (s. 121-140). Toruń: Wydawnictwo Uniwersytetu Mikołaja Kopernika.

Marciniak A.

2000 Paradygmaty badawcze w archeologii. W: S. Tabaczyński, A. Marciniak, D. Cyngot, A. Zalewska (red.), Przeszłość spoteczna. Próba konceptualizacji (s. 27-83). Poznań: Wydawnictwo Poznańskie.

Minta-Tworzowska D.

2000 Kwestia przełomu metodologicznego w prahistorii i w archeologii polskiej. W: M. Kobusiewicz, S. Kurnatowski, Archeologia i prahistoria polska $w$ ostatnim pótwieczu (s. 527-535). Poznań: Wydawnictwo Poznańskiego Towarzystwa Przyjaciół Nauk.

Niesiołowska-Śreniowska E.

1983 Osada z fazy AB kultury pucharów lejkowatych na stanowisku 1A w Sarnowie, województwo włocławskie, w świetle materiałów krzemiennych i niektóre problemy z nią związane. Prace i Materiaty Muzeum Archeologicznego i Etnograficznego w Lodzi. Seria Archeologiczna, 30, s. 201-251. 
Nowak M.

2009 Drugi etap neolityzacji ziem polskich. Kraków: Instytut Archeologii Uniwersytetu JaRączkowski W. giellońskiego.

2009 Theory, empiria and practitioner (practice) archaeological discources in (to) network of [2011] dependance and resistance. Teoria, empiria i praktyka: archeologiczne dyskursy w sieci zależności i opozycji. Analecta Archaeologica Resoviensia, 4, s. 7-23.

Schild R.

1980 Introduction to dynamic technological analysis in chipped stone assemblages. W: R. Schild (red.), Unconventional Archaeology (s. 57-85). Wrocław: Zakład Narodowy im. Ossolińskich.

Schild R.

2000 Paleolit schyłkowy na Niżu Polskim. W: M. Kobusiewicz, S. Kurnatowski (red.), Archeologia i prahistoria polska w ostatnim półwieczu (s. 39-46). Poznań: Wydawnictwo Poznańskiego Towarzystwa Przyjaciół Nauk.

Schild R., Marczak M., Królik H.

1975 Późny mezolit. Próba wieloaspektowej analizy otwartych stanowisk piaskowych. Wrocław-Warszawa-Kraków-Gdańsk: Ossolineum.

Słowikowski A.

2009 Obraz czlowieka w polskiej archeologii XX wieku. [Maszynopis pracy magisterskiej, Instytut Archeologii Uniwersytetu Mikołaja Kopernika, Toruń].

Szmyt M.

1996 Społeczności kultury amfor kulistych na Kujawach. Poznań: Wydawnictwo im. A. Mickiewicza w Poznaniu.

Tabaczyński S.

2000 „Wymuszony przewrót metodologiczny” w archeologii polskiej i jego nieoczekiwane skutki. W: M. Kobusiewicz, S. Kurnatowski (red.), Archeologia i prahistoria polska w ostatnim pótwieczu (s. 513-525). Poznań: Wydawnictwo Poznańskiego Towarzystwa Przyjaciół Nauk.

Zakościelna A.

1996 Krzemieniarstwo kultury wołyńsko-lubelskiej ceramiki malowanej. Lublin: Wydawnictwo Uniwersytetu Marii Curie-Skłodowskiej.

Zybertowicz A.

1995 Przemoc i poznanie. Studium z nie-klasycznej socjologii wiedzy. Toruń: Wydawnictwo Uniwersytetu Mikołaja Kopernika.

\section{ON NEOLITHIC FLINT-KNAPPING AND NEOLITISATION OF POLISH LANDS - ABOUT THE THEORY, METHODS AND LANGUAGE}

\section{Su m mary}

In 1988 and 1989, in a journal Archeologia Polski, Jacek Lech published two articles, which might be seen as the first attempt by the researchers in the late 1980s of critical reflection on theoretical, methodological and methodical basics adopted in the studies on flint working of early 
farming communities in the Vistula and Odra river basins. Lech's statement concerned the archaeological reality in which two visions of practising archaeology, now referred to as paradigms, cultural-historical and processual, associated with the New Archaeology, clashed. In his conclusions, Lech emphasised methodological weakness of many published works concerning neolithic flint working, naming procedures applied by some researchers a "hypothetical-inductive method".

In this article, with reference to the critical approaches Lech presented 25 years ago, an attempt has been made to assess theoretical, methodological and methodical basics of works concerning the neolithic flint working in the next 25 years, and especially in the recently published extensive monographs devoted to this category of evidence. Their authors have applied the method of classification, adopted from the classic monograph by Schild, Marczak and Królik Późny mezolit. Próba wieloaspektowej analizy otwartych stanowisk piaskowych [The late Mesolithic. An example of multiaspectual analysis of open air sites from sandy lowlands], published in 1975, written in the spirit of the processual methodology. Textual analysis of this monograph revealed consistent compliance with the processual rules of producing archaeological knowledge. Level I has consisted in detailed analysis of archaeological evidence, including application of statistical methods. Level II has combined the data obtained at level I with theory (primarily anthropological), which permitted formulating cultural meanings. These, in turn, allowed presentation/ reconstruction of a fragment of past social reality.

An attempt to assess, published in recent years, monographs concerning flint working in terms of their theoretical assumptions and methodology of research procedures has led to several conclusions. First of all, declarations of applying the classification scheme of materials as presented in Schild, Marczak and Królik's work do not implicate any assumption of a method for producing knowledge. The second level that is the application of a proper anthropological theory to combine knowledge resulting from detailed, multi-dimensional analyses of evidence into a coherent vision of a past reality, in the case of discussed syntheses of neolithic flint working is restricted to an adoption of already existing conclusions, made on the basis of other archaeological sources (mainly pottery). Flint materials are in some sense a necessary addition (due to the fact they co-occur with other materials) which should be "studied" while conclusions resulting from their analysis depend on the non-flint-related results. They have provided a combination (which could hardly be called creative) of certain analytical procedures and quite superficial textual layer, adopted from processual mainstream with the practice characteristic for the cultural-historical school.

Translated by Lucyna Leśniak 